\title{
КОЛОНІЗАЦІЯ ОЧАКІВСЬКОЇ ОБЛАСТІ ЧОРНОМОРСЬКИМ КОЗАЦЬКИМ ВІЙСЬКОМ
}

Анотація. У статті розглядаються окремі аспекти територіального оформлення Чорноморського війська під час його перебування в Буго-Дністровському межиріччі, а саме господарське освоення земель, наданих чорноморцям урядом Російської імперії, на жаль, на дуже короткий час. В 1790 р. "довгоочікувана» Очаківська область, яка відкривала шлях до Чорного моря, нарешті була звільнена від турків і потрібно було їі якнайшвидше заселяти, укріплюючи при цьму південні рубежі. Для цього найкраще підходили чорноморці, які геройськи проявили себе під час військових дій російсько-турецької війни. Невдовзі на території Подністрянської паланки козаки проживали в поселеннях: Аджидер, Біляївка (Головківка), Глинне, Гоголівка (неподалік від Маяків), Калаглія, Карагач, Коротне, Котлярівка друга, Кучургани, Миколаївка, Незавертай (Незавертайлівка), Суклея, Паркани, Петровка, Терновка, Чобручі, Яськи тощо. Ключові слова: Чорноморське військо, Очаківська область, Бугу-Дністровське межиріччя, козаки, колонізація.

Lozheshnyk Aleksandr

Odesa I.I. Mechnikov National University

\section{COLONIZATION OF OTCHAKIV AREA BY BLACK SEA COSSACK ARMY}

Summary. In the article the separate aspects of territorial registration of the Black Sea army are examined during his in the Bug-Dniester country between, namely economic land given to чорноморцям by the government of the Russian empire development, unfortunately, on very short time. In 1790 the "long-awaited" Otchakiv area that opened a way to the Black sea was finally released from turks and it was needed her as quick as possible to occupy, strengthening south borders here. For this purpose Chernomorets that heroically proved during the military operations of Russian-Turkish war befitted better in all. Knowing, as cossacks need own earth, a prince H. Potomkin "semi-official presented" earth south of way" of "Bendery, "designing" thus territorial existence of the black Sea army in the Bug-Dniester country between. Indeed "registration" of army was only on words, original "acceding" to tsar's government that provided itself faithful guards. Soon on territory of Transnistria of palanquins cossacks lived in settlements: Adzhyder, Biliaivka (Holovkivka), Hlynne, Hoholivka (not far away from Maiakiv), Kalahliia, Karahach, Korotne, Kotliarivka second, Kuchurhany, Mykolaivka, Nezavertai (Nezavertailivka), Sukleia, Parkany, Petrovka, Ternovka, Chobruchi, Yasky and others like that. Indeed, the cossack villages of cossacks abutted upon squire and municipal earth and villages of state peasants - such to the soba the strip farming caused "award" by tsar's government of the enormous landed parcels of land to the proteges. Soon exactly these squire estates and became principal reason of migration of army on Tamanskyi peninsula. Thus, the cossacks of the black Sea army lived on territory of the Bug-Dniester country between only a few years, and remembrances about them living and until now. Every settlement founded by Chernomorets has the history that is passed to the descendants.

Keywords: the Black Sea troops, Ochakiv region, Buh-Dnister interfluve, cossacks, colonization.

Постановка проблеми. Сьогодні, коли

11 «Російська імперія» знову виставляе свої рахунки на привласнення українських земель, все частіше згадуеться те, як вона вчинила із Чорноморським іррегулярним формуванням нащадком славного Запорозького війська.

Створення Чорноморського війська на території Південної України наприкінці XVIII ст., не дивлячись на свою доцільність, розглядалось урядом як тимчасове явище. Тому він і зволікав у наданні офіщійного дозволу на заселення відведеної для нього території. Навпаки, закріпивши свої позиції на р. Дунай та узбережжі Чорного моря підписанням в 1791 р. Ясської угоди, він почав ціленапрвлено виводити козаків 3 півдня України, переселяючи їх на Кубань. Та не дивлячись на всі перешкоди, за короткий проміжок свого функціонування в Буго-Дністровському межиріччі формування залишило значний слід на ниві господарського освоєння краю. Після переселення на Кубань воно продовжило традиціі своїх попередників і стало зразком для спадкоємців. Соціально-економічне становище та заходи щодо колонізації чорноморців $е$ цікавим і корисним досвідом для сьогодення.

Аналіз останніх досліджень та публікацій. Після проголошення суверенності України, коли суспільно-політичні зміни в країні зняли цензурні політико-ідеологічні обмеження, відкрили нові можливості для вивчення іррегулярного фрормування, бойового шляху чорноморців, ïx господарювання та відношення 3 урядом, з'явилися дослідження вчених, які дають змогу по новому подивитись на проблеми заселення межиріччя козаками. Зокрема, А. Бачинський підтвердив перебування чорноморців після масового переселення на Кубань в Буго-Дністровському межиріччі та існування Чорноморської козацької команди в Одесі [7, с. 50]. У співавторстві з О. Бачинською вчений усесторонне розглянув основні моменти історії війська, особливості господарського життя козаків. Окрім того, автори зробили досить вдалу спробу відтворити модель поведінки козаків після ліквідації Запорозької Січі і показали спадковість Січі й Чорноморського війська [6]. 
Різні аспекти даної проблеми продовжують досліджувати I. Анцупов [1; 2], О. Бачинська [5], Т. Гончарук [10; 11; 13], С. Гуцалюк [12], С. Аргатюк [3; 4], Р. Шиян [26; 27], що не лише по новому «читають» та аналізують опубліковані документи, а й опублікували значний комплекс нововиявлених архівних матеріалів.

Виділення невирішених раніше частин загальної проблеми. Розпочавши формування в 1783 р. полку із колишніх запорожців, князь Г. Потьомкін відразу ж підняв питання щодо їх оселення. Зокрема, 6 квітня 1784 р. він прохав Катерину II переселити тисячний полк колишніх запорожців на лівий берег Дніпра [15, с. 20], на малозаселену частину території колишнього Запоріжжя. Уряд, усвідомлюючи небезпеку створення подібного війська, довгий час зволікав із прийняттям рішення. Лише 14 січня 1788 p. Катерина II дозволила Г. Потьомкіну вирішити питання військової території на власний розсуд (а не офріційно), враховуючи прохання та побажання козаків, які нібито хотіли оселитися в «Керченському Куті або на Тамані» [23, с. 529].

Остаточного вирішення територіального питання чорноморці чекали до 1790 р., коли за наказом гетьмана Г. Потьомкіна від 1 березня були передані «в повне розпорядження» отаману 3. Чепізі, «військовим старшинам та всьому товариству» $[18$, с. $11-12,38]$, щоправда знову без офіційного дозволу Катерини II, землі Очаківської області (Буго-Дністровське межиріччя), що офіційно належали ще Оттоманській Порті.

Мета дослідження полягае в об’ективному висвітленні особливостей поселення та ролі в господарському освоєнні козаків Чорноморського війська в Буго-Дністровському межиріччі наприкінці XVIII ст.

Реалізація поставленої мети у цій науковій статті передбачає розв'язання наступних завдань:

1) проаналізувати стан наукової розробки та ступінь репрезентативності джерельної бази дослідження наприкінці XX - на початку XXI ст.;

2) з'ясувати роль чорноморців у господарському освоєнні Буго-Дністровського межиріччя.

Об’ект дослідження: козаки Чорноморського війська.

Предмет дослідження: колонізація козаками Чорноморського війська Буго-Дністровського межиріччя.

Виклад основного матеріалу дослідження. В 1790 р. "довгоочікувана» Очаківська область (землі між Дністром, Бугом, Чорним морем та річками Ягорлик й Кодима на півночі), яка відкривала шлях до Чорного моря, нарешті була звільнена від турків і потрібно було ії якнайшвидше заселяти, укріплюючи при цьому південні рубежі. Для цього найкраще підходили чорноморщі, які геройськи проявили себе під час військових дій російсько-турецької війни. Знаючи, як козакам потрібна власна земля, князь Г. Потьомкін "напівофіційно подарував» [18, с. 11-12] землі на південь від «Бендерського шляху», «оформивши» таким чином територіальне існування Чорноморського війська в Буго-Дністровському межиріччі. Щоправда «оформлення» війська було лише на словах, своєрідною «угодою» 3 царським урядом, який забезпечував себе вірними охоронцями.
Війську були надані величезні площі орних земель, пасовиськ та сінокосів, очеретяних заплав, місця для риболовлі та соледобування (майбутні Одеські соляні промисли), пасіки та ліси. I хоча продовжувалась війна, чорноморці відразу ж нетерпеливо почали облаштовувати своє, як вони тоді думали, постійне місце проживання. Окрім переселення в «чужі» слободи та хутори, за наказом Г. Потьомкіна на території Одещини на місці зимівників влаштовувалися «власні». Їхні назви до сьогодні зберегли пам'ять про ті часи: село Іванівка названо від імені власника зимівника Івана Чигиринця, с. Олексіївка - Олексія Петренка; с. Андріївка - Андрія Сологуба, с. Олександрівка - Олександра Шпака. Усатовський хутір (с. Усатово) названо на честь заможного козака Чорноморського війська Тимофія Усатого [28, с. 13]. В деяких випадках представники запорозької старшини, з дозволу князя Г. Потьомкіна, перетворювали свої зимівники на маєтки $[8$, с. 17], де займались господарством та промислами.

Невдовзі на території Подністрянської паланки $[19$, с. 80-91] (компактно, в смузі від Чорного моря до с. Терновка в околицях м. Тирасполь) козаки проживали в поселеннях: Аджидер, Біляївка (Головківка), Глинне, Гоголівка (неподалік від Маяків), Калаглія, Карагач, Коротне, Котлярівка друга, Кучургани, Миколаївка, Незавертай (Незавертайлівка), Суклея, Паркани, Петровка, Терновка, Чобручі, Яськи тощо [2, с. 162-163; 9 , с. 152]. За далеко не повними даними в період з 1790 р. до серпня 1792 р. кількість чорноморських козаків збільшилась з 2000 до 6000 осіб (близько 1500 козацьких родин), які проживали в 30 поселеннях $[14$, с. $17 ; 20$, с. $29 ; 24$, с. 11].

Щоправда, станиці козаків межували з поміщицькими та міськими землями й селами державних селян - така собі черезполосиця, спричинена «пожалуванням» царським урядом величезних земельних наділів своїм ставленикам. Невдовзі саме ці поміщицькі маєтки й стали основною причиною переселення війська на Таманський півострів, але про це чорноморці в 1790 р. ще не знали: вони несли прикордонну службу по лівому березі Дністра, брали участь в боях на Дунаї та за Дунаем і, звичайно ж, у вільний час займались господарством на території ще офіційно не визнаної Очаківської області.

Поселене на "новопридбаних» землях Чорноморське військо все більше притягувало до себе колишніх запорожців, що тікали з поміщицьких земель, де вони не лише встигли оселитись, а й частково були навіть закріпачені. Разом із запорожцями до «коша» у м. Слободзеї, де проживало 130 козацьких родин, втікали й інші селяни, що потрапили в залежність від поміщиків. Приваблювало їх і те, що козацька адміністрація не видавала втікачів. За рахунок "втікачів», козаків та «підданих», військо постійно зростало. Воно було спроможне жити на самозабезпеченні, за винятком підрозділів, які перебували на фронті та отримували державне забезпечення - кошти, фораж, порох, свинець, частково амуніцію.

За дії в бойових операціях військо кров’ю виборювало право на свое існування. Можливо тому, коли мова йшла про повну чи часткову ліквідацію після закінчення війни Катеринослав- 
ського, Бузького та Українського військ, питання про Чорноморське військо не піднімалось. Після підписання Ясського миру 29 грудня 1791 р. (за старим стилем та 9 січня 1792 р. за новим стилем) воно як і раніше контролювало ситуацію на лівому березі Дністра, займалось сільськогосподарським виробництвом, розбудовувало поселення, користувалось щедрими промислами (рибними та соляними), саджало сади та виноградники, займалось бджільництвом, баштанами, шовківництвом, збільшувало поголів'я худоби та відроджувало роль промислових традицій.

Все було б спокійно і надалі, якщо б не чергові плани царського уряду. I на цей раз Чорноморському війську в них місця не було. Чорноморці ще не знали, що відразу ж після підписання Ясської угоди Катерина II спеціальним указом від 27 січня наказала Катеринославському губернатору Василю Каховському оглянути новопридбану Очаківську область, щоб «розділити її на повіти, призначити міста за здатністю, і про їй та Сенату представити» [25, с. 259]. I жодного слова, як і в подальших наказах, не було мовлено про чорноморців - про них просто забули. Пройде ще півроку i, після чисельних «прохань» козаків «з ласки» Катерини II, їх переселять на ще один небезпечний рубіж - захищати кордони Російської імперії.

Отже, козаки Чорноморського війська прожили на території Буго-Дністровського межиріччя лише декілька років, а спогади про них живі й до сьогодні. Кожне поселення, засноване чорноморцями, має свою історію, яка передається нащадкам.

Наприклад, першими осілими мешканцями Хаджибея (Одеси) по праву можна назвати козаків: у грудні 1793 р. в Хаджибеї в 10 дворах проживало 28 козаків з їх родинами та 10 цивільних мешканців [17, с. 256]. Вважаючи цю територію "своєю», чорноморці поряд із гарнізоном регулярних військ після звільнення фрортеці в 1789 р. залишили тут комендантом, «полковником Аджебея» чорноморського козака, який відповідав за облаштування у Слободзеї головної квартири, поселення чорноморців в Буго-Дністровському межиріччі, контролював забезпечення всім необхідним козаків, що брали участь у військових діях. Зокрема, у вересні 1790 р. він рапортував кошовому 3. Чепізі про «постачання 3 Березані та Аджибея до військових човнів дерева, мотузок та інших матеріалів» [16, с. 200].

Першопоселенцями с. Чубаївки (тепер мікрорайона м. Одеси в так званій Чубаївській балці) стали «чубаті» чорноморські козаки. Існуе й інша, місцева легенда, що після штурму фортеці Хаджибей у вересні 1789 р. козаки оселились в одному з урочищ, які оточували фортецю, а одним з перших побудував тут свій будинок козак Чуб.

Перші згадки в писемних джерелах про село (хутір) Головківку датуються 1792 р., у зв'язку 3 повідомленням до Коша осавула Ніякого [22, с. 29]. Існуе кілька версій походження його назви, проте усі вони пов'язані з іменем полковника А. Головатого. За однією з версій хутір був заснований Головатим тому, що неподалік, всього у 50 кілометрах від цього місця, розміщувався Кіш та канцелярія Чорноморського козацького війська; за іншою версією, ніби-то Антон Головатий розбив хутір на землях, що належали йому.
Так чи інакше, але хутір на довгий час отримав назву Головківка за ім'ям власника.

Першими жителями Головківки були 25 козащьких родин, яким довелось винести багато труднощів. Для них на той час було проблематичним вирішення питання житла, перевезення сім'ї на нове місце проживання. Разом $з$ цим потрібно було займатися і будівництвом господарчих будівель для коней та худоби. До того ж вибрати місце для церкви. Та козаків це не лякало. На 30 листопада 1791 р. в селищі нараховувалось 36 дворів, де проживало 92 чоловік та 74 жінки [21, с. 151-153]. I все це відбувалося паралельно 3 несенням військової служби, в постійній готовності до військових дій з турками та татарами.

Пов'язана is старшиною Чорноморського війська і друга (теперішня) назва Головківки - Біляӥвка, яка також має декілька версій. За першою з них: землі, на яких розміщено село, належали першому кошовому отаману С. Білому; за другою - село названо на честь шанованого отамана (на території Очаківської землі існуе декілька Біляївок, які виникли на всьому шляху, по якому проходили війська Сидора Білого); за третьою - село розміщене на землях, де мріяв оселитись після російсько-турецької війни 1787-1791 pр. кошовий отаман С. Білий. Щоправда, існуе й інша версія: у Чорноморському війську служило декілька козаків на прізвище Білий. Зокрема, полковник Сава Білий, хорунжий Андрій Білий, тощо. Можливо, землі на яких розташована сучасна Біляївка, належали комусь 3 них.

Одну 3 найважливіших галузей господарства чорноморців складало рибальство. Воно набувало першочергового значення і тому, що в даний період господарства чорноморців ще не встигли зміцніти. А більшість козаків взагалі проживали поза військовою територією. В зв'язку з цим привертає до себе увагу історія села Калаглія Овідіопольського району, розташованого вздовж Карагольської затоки Дністровського лиману (в межах сучасної Миколаївки). Воно було засноване у 1790-1791 рр. як рибальське селище 6 родинами козаків Чорноморського війська: осавулом Федором Бурносом, Максимом Кирсановим, прем'ер-майором Давидом Білим, Скульським, Олексіем Височином.

Подібну історію має й село Миколаївка: на їі території в 1790-1792 рр. розміщувалась слобода Дністрова (Рибацька) з хуторами Коса Велика, Калаглійська коса (Калаглійський), де займались риболовством чорноморці.

Цікаві своєю козацькою історією і селища Куяльник, Усатівські і Нерубайські хутори, Холодна балка та Великий Фонтан, де козаки добували камінь для потреб міста, що почало будуватись на місці фортеці Хаджибей - Одеси.

Висновки. Оселення в Буго-Дністровському межиріччі сприяло розвитку козацьких господарств та виникненню багатьох поселень за короткий час. Їх локалізащія довела, що козаки здебільшого селились поближче до військового Коша в с. Слободзеї. Була ще одна перепона повноцінній колонізації: чисельність війська, навіть разом 3 їх родинами було недостатньою для повноцінного освоювання величезної за розмірами території.

Слід зазначити й те, що хоча й проживаючи в межиріччі чорноморці були забезпечені достат- 
ньою кількістю родючої землі, промисловими угіддями та очеретяними заплавами, але ні те, ні інше не використовували для товарообороту. 3 одного боку, це було через те, що закон не наділив козаків правом власності на землю, не дозволив розпоряджатися наділами як власним майном. А з іншого - являлось надійною запорукою їх економічної згуртованості, яка окрім всього підкріплялась давніми традиціями - «жили за старими запорозькими звичаями».

\section{Список літератури:}

1. Анцупов И. А. Казаки и военные поселенцы на Днестре и Буге XVIII-XIX веков. Ежегодный исторический альманах Приднестровья. 1997. № 1. С. 30-39.

2. Анцупов И. А. Казачество российское между Бугом и Дунаем. Кишинев, 2000. 290 с.

3. Аргатюк С. Аджидер-Овидиополь. Одесса, 2015. 312 с.

4. Аргатюк С. Татарка-Прилиманське. Одеса, 2006. 248 с

5. Бачинська О. А. Козацтво в «післякозацьку» добу української історії (кінець XVIII-XIX ст.). Київ, 2011.287 с.

6. Бачинський А. Д., Бачинська О. А. Козацтво на Півдні України 1775-1869 рр. Одеса : Маяк, 1995.56 с.

7. Бачинський А. Хаджибей-Одеса і українське козацтво // Одесі - 200: тези доп. Міжнар. наук.-теорет. конф. Одеса, 1994. Ч. 1. С. 49-51.

8. Бойко А. В. Запорозький зимівник останньої чверті XVIII століття. Запоріжжя, 1995. 255 с.

9. Голобуцкий В. А. Чорноморське козацтво за Бугом. Наукові Записки Інституту історії АН УРСР. Київ, 1952. T. 4. С. 133-154.

10. Гончарук Т. Г. Григорій Потьомкін - гетьман українського козацтва. Одеса, 2002. 141 с.

11. Гончарук Т. Г. История Хаджибея (Одессы). 1415-1795 гг. Одесса, 1997. 88 с.

12. Гончарук Т., Гуцалюк С. Українське козацтво та Хаджибей (Одеса). Середина XVI ст. - 1794 р. Одеса, 1998.67 с.

13. Гончарук Т. Г. Участь чорноморських козаків у військових діях під час російсько-турецької війни 1787-1791 років. Одеса козацька. Одеса, 2008. С. 39-54.

14. Григорович В. И. Записка о пособиях к изучению Южно-русской земли, находящихся в Военно-ученом архиве Главного штаба. Одесса, 1876. С. 17.

15. Дмитренко И. И. Сборник исторических материалов по истории Кубанского казачьего войска : в 4 т. СПб., 1896. Т. 1: 1737-1801. 897 c.

16. Дмитренко И. И. Сборник исторических материалов по истории Кубанского казачьего войска. СПб., 1896. Т. 3: 1787-1795. 799 c.

17. Дружинина Е. И. Северное Причерноморье 1775-1800. М., 1959 г. 277 с.

18. Дубровин Н. Ф. Сборник военно-исторических материалов. СПб., 1895. Вып. 8.375 с.

19. Иванов П. А. Черноморские казаки в Слободзее // ЗООИД. Одесса, 1902. Т. 24. С. 80-91.

20. Короленко П. П. Черноморцы. СПб, 1874. С. 29.

21. Материалы для оценки земель Херсонской губернии. Херсон, 1883. Т. 2. 385 с.

22. Одеса і одесити в III тисячолітті. Підприемства. Організації. Установи. Персоналії. Міста і села Одеської області. Київ, 2008. 590 с.

23. Полное собрание законов Российской империи. Собрание первое / под ред. М. М. Сперанского. СПб.: Тип. 2 Отд. Собств. Его Имп. Величества канцелярии, 1830. Т. 22: 1784-1788. 1174 с.

24. Скальковский А. Опыт статистического описания Новороссийского края и Бессарабии. Одесса, 1850.386 с.

25. Скальковский А. Сравнительный взгляд на Очаковскую область в 1790 и 1840 гг. // ЗООИД. Одесса, 1844. T. 1. C. $257-277$.

26. Шиян Р. I. Козацтво Південної України останньої чверті XVIII ст. Запоріжжя : Тандем-У, 1998. 98 с. 233.

27. Шиян P. I. Чорноморське військо вірних козаків в останній чверті XVIII ст. Запоріжжя : Тандем-У, 1996. 28 с.

28. Яковлев В. А. К истории заселения Хаджибея 1789-1795 г.: к истории завоевания Хаджибея. Одесса, 1889.57 с.

\section{References:}

1. Antsupov I. A. (1997) Kazaki i voyennyye poselentsy na Dnestre i Buge XVIII-XIX vekov [Cossacks and soldiery settlers on Dnister and Bug of XVIII-XIX of centuries]. Annual historical almanac of Pridnestrovya, no. 1, pp. 30-39.

2. Antsupov I. A. (2000) Kazachestvo rossiyskoye mezhdu Bugom i Dunayem [The cossacks are Russian between Bug and Danube]. Kishinev. (in Russian)

3. Argatyuk S. (2015) Adzhider-Ovidiopol [Adzhider-Ovidiopol]. Odessa. (in Ukrainian)

4. Argatyuk S. (2006) Tatarka-Prylymanske [Tatarka-Prylymanske]. Odesa. (in Ukrainian)

5. Bachynska O. A. (2011) Kozatstvo $v$ "pisliakozatsku» dobu ukrainskoi istorii (kinets XVIII-XIX stolittia) [The cossacks are in "postcossack" time of Ukrainian history(end of XVIII-XIX to the century)]. Kyiv. (in Ukrainian)

6. Bachynskyi A. D. (1995) Kozatstvo na pivdni Ukrainy (1775-1869) [The cossacks are on South of Ukraine (1775-1869)]. Odesa. (in Ukrainian)

7. Bachynskyi A. (1994) Khadzhybei-Odesa i ukrainske kozatstvo [Hadjibey-Odessa and the Ukrainian cossacks]. Odessa - 200. Odessa, vol. 1, pp. 49-51.

8. Boiko A. V. (1995) Zaporozkyi zymivnyk ostannoi chverti XVIII stolittia [The Zaporizhzhya winterer of the last fourth XVIII is a century]. Zaporizhzhia. (in Ukrainian)

9. Golobutskiy V. A. (1952) Chornomorske kozatstvo za Bugom [The black sea cossacks are after Bug]. Scientific Messages of Institute of history of Academy of sciences of the Ukrainian soviet socialistic republic. Kyiv, vol. 4, pp. 133-154.

10. Goncharuk T. H. (2002) Hryhorii Potomkin - hetman ukrainskoho kozatstva [Hryhorii Potomkin - is a hetman of the Ukrainian cossacks]. Odesa. (in Ukrainian)

11. Goncharuk T. G. (1997) Istoriya Khadzhibeya (Odessy). 1415-1795 gg. [History of Hadjibey (Odesa). 1415-1795]. Odessa. (in Ukrainian)

12. Honcharuk T., Hutsaliuk S. (1998) Ukrainske kozatstvo ta Khadzhybei (Odesa). seredyna XVI st. - 1794 r. [The Ukrainian cossacks and Hadjibey (Odessa). Middle of XVI of century - in 1794]. Odessa. (in Ukrainian)

13. Honcharuk T. H. (2008) Uchast Chornomorskykh kozakiv u viiskovykh diiakh pid chas rosiisko-turetskoi viiny 1787-1791 rokiv. Odesa is cossack. Odessa, pp. 39-54. 
14. Grigorovich V. I. (1876) Zapiska o posobiyakh k izucheniyu Yuzhno-russkoy zemli, nakhodyashchikhsya v Voyennouchenom arkhive Glavnogo shtaba [Message about manuals to the study of South-Russian earth, being in the Military-scientific archive of the Main staff]. Odessa. (in Ukrainian)

15. Dmitrenko I. I. (1896) Sbornik istoricheskikh materialov po istorii Kubanskogo kazachyego voyska [Collection of historical materials on history of the Kuban cossack army]. Sankt-Peterburg, vol. 1: 1737-1801. (in Russian)

16. Dmitrenko I. I. (1896) Sbornik istoricheskikh materialov po istorii Kubanskogo kazachyego voyska [Collection of historical materials on history of the Kuban cossack army]. Sankt-Peterburg, vol. 3: 1787-1795. (in Russian)

17. Druzhinina YE. I. (1959). Severnoye Prichernomorye 1775-1800 [North black sea Region 1775-1800]. Moscow. (in Russian)

18. Dubrovin N. F. (1895) Sbornik voyenno-istoricheskikh materialov [Collection of military historical materials]. Sankt-Peterburg, vol. 8. (in Russian)

19. Ivanov P. A. (1902) Chernomorskiye kazaki v Slobodzeye [Black sea cossacks are in Slobodzee]. Messages of Odesa society of history and antiquities. Odessa, vol. 24, pp. 80-91.

20. Korolenko P. P. (1874). Chernomortsy [Chernomorets]. Sankt-Peterburg. (in Russian)

21. Statisticheskoye otdeleniye pri Khersonskoy gubernskoy zemskoy uprave (1883). Materialy dlya otsenki zemel Khersonskoy gubernii [Material for the estimation of earth of the Kherson province]. Kherson, vol. 2. (in Ukrainian)

22. Odeska oblasna derzhavna nasinnyeva inspektsiya (2008). Odesa i odesyty v tretmu tysiacholitti. Pidpryiemstva. Orhanizatsii. Ustanovy. Personalii. Mista i sela Odeskoi oblasti [Odesa and Odesa are in the third millennium. Enterprises. Organizations. Establishments. Personalias. Cities and villages of the Odesa area]. Kyiv. (in Ukrainian)

23. Speranskiy M. M. (1830) Polnoye sobraniye zakonov Rossiyskoy imperii. Sobraniye pervoye [Complete collection of laws of the Russian empire. Collection first]. Sankt-Peterburg, vol. 22: 1784-1788. (in Russian)

24. Skalkovskiy A. (1850) Opyt statisticheskogo opisaniya Novorossiyskogo kraya i Bessarabii [Experience of statistical description of the Novorossisk edge and Bessarabia]. Odessa. (in Ukrainian)

25. Skalkovskiy A. (1844) Sravnitelnyy vzglyad na Ochakovskuyu oblast v 1790 i 1840 gg. [Comparative look to the Ochakiv area in 1790 and 1840]. Messages of Odesa society of history and antiquities. Odessa, vol. 1, pp. $257-277$.

26. Shyian R. I. (1998) Kozatstvo Pivdennoi Ukrainy Ostannoi chverti XVIII st. [The cossacks of South Ukraine of the last fourth of XVIII of century]. Zaporizhzhia. (in Ukrainian)

27. Shyian R. I. (1996) Chornomorske viisko virnykh kozakiv v ostannii chverti XVIII st. [A black sea army of faithful cossacks is in the last fourth of XVIII of century]. Zaporizhzhia. (in Ukrainian)

28. Yakovlev V. A. (1889) K istorii zaseleniya Khadzhibeya 1789-1795g.: k istorii zavoyevaniya Khadzhibeya [To history of settling of Hadjibey of 1789-1795: to history of conquest of Hadjibey]. Odessa. (in Ukrainian) 